\title{
TEXTILE MATERIALS AS BARRIERS AGAINST ELECTROMAGNETIC RADIATION
}

\author{
Bosiljka Šaravanja*, Krešimir Malarić**, Tanja Pušić* \\ ${ }^{*}$ University of Zagreb, Faculty of Textile Technology, Zagreb, Croatia \\ ** University of Zagreb, Faculty of Electrical Engineering and Computing, Zagreb, Croatia
}

corresponding author: Tanja Pušić, e-mail: tpusic@ttt.hr

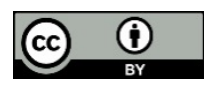

This work is licensed under a

Creative Commons Attribution 4.0

$\underline{\text { International License }}$
Original scientific paper

Received: June $28^{\text {th }}, 2019$

Accepted: August 10 $0^{\text {th }}, 2019$

HAE-1916

https://doi.org/10.33765/thate.9.4.1

\begin{abstract}
The accelerated development of textile products that have shielding properties against electromagnetic (EM) radiation excites the interest of scientists, the textile and clothing industry in the manufacture of woven fabrics, knitted fabrics and clothing with shielding properties. This paper deals with the investigation of the shielding effect of the electroconductive fabric to be used for manufacturing protective clothing consisting of textile and non-textile components. The textile component is a cotton-modacrylic blend, and the non-textile component is an inox yarn inserted into the fabric every $1 \mathrm{~cm}$ in the transverse direction of the fabric. The fabric was finished using solvents in the processes of dry and wet cleaning as potential care processes. The measurement results of shielding fabric properties have shown that the degree of shielding is better preserved after 10 cycles of wet cleaning than after dry cleaning.
\end{abstract}

Keywords: electroconductive fabric, shielding effect, dry cleaning, wet cleaning

\section{INTRODUCTION}

Field and waves of wireless technologies (GSM or global system for mobile communications, the internet, etc.) are nonionizing microwave electromagnetic (EM) radiations [1]. The development and use of mobile phones and various electronic devices raises the interest of scientists in different areas. Intensive development of new technologies and products, e.g. electrical and electronic devices, implies the need to control the negative impact and the possibilities of their prevention. Various medical research activities have shown that the frequent use of electronic and electrical devices can affect an increase in stress, insomnia, headaches, heart arrhythmias as well as an increase in the percentage of cancer diseases, behaviour changes etc. [2 - 6].

Electromagnetic radiation hazard is thus higher, since negative consequences are noticed only after a long period of time, and are usually not associated with EM pollution but with other factors (poor nutrition, accelerating pace of life, stress and so on). Therefore, the EM emission limits of all 
electrical and electronic devices are set so as to minimize the possibility of interference with radio and wireless communications. When EM rays pass through the medium or material [5], they interact with material molecules, and this interaction phenomenon can be divided into three parts:

- absorption,

- reflection,

- secondary reflection.

When EM rays hit the material surface, they push the charge in the material to oscillate. This forced charge oscillation behaves as an antenna and results in reflection. The second part is converted into heat energy due to oscillation. This kind of signal loss is known as weakening due to absorption. Thus, the shielding property of the material against electromagnetic radiation is based on the reflection from the conductive surface and the absorption in the conductive volume. Part of the wave is reflected, while the rest is transmitted and weakened while passing through the medium, Figure 1.

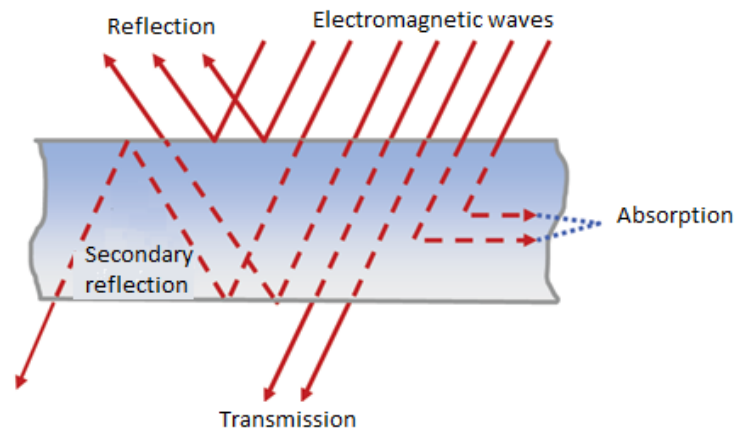

Figure 1. Schematic representation of signal spreading through the material with protective properties [5]

The shielding effect of the conductive barrier $(\mathrm{dB})$ is the sum of reflection losses (R), absorption loss (A) and secondary reflection loss (Rr). The combined effect of these losses (reflection and absorption) determines the effectiveness of shielding properties of the material which depend on:

- electric and magnetic properties,
- conductivity properties on the surface and in the inside,

- material thickness,

- material composition.

With respect to all of these hazards and risks that occur due to exposure to sources of electromagnetic radiation there is a growing need to find ways of shielding against radiation. Among the various solutions offered, the attention of researchers has been attracted by textile products and composite textile-based materials due to their diverse application and conformity [7 - 11].

Conductive textile structures can be designed in various ways. Fabrics with a different degree of electroconductivity can be designed from yarns made of filament or cut fibers in combination with traditional non-conductive fibers. Another way of producing an electro conductive structure is achieved by coating textile substrates with conductive substances, which do not impair the fundamental substrate properties [12]. It is possible to achieve satisfactory conductivity of fabric through the incorporation of conductive particles into the fibers, with at least $15 \%$ of conductive particles [12].

Studies were conducted in which the influence of material type, metal presence in the material, number of threads, weaving density, number of coats and number of layers was investigated. Shielding properties of fabric against EM radiation increase with the increasing number of layers, with decreasing yarn fineness and with the presence of metals in the fabric [13 - 15].

The paper deals with the influence of solvents on shielding properties of electroconductive modacryl/cotton blend fabric with inox threads. Its application area is the manufacture of work clothes for employees at petrol stations, power lines, gas works, and other power plants where they need protection due to a high intensity of the electromagnetic field. Considering that this fabric is intended for making work wear, the influence of the care process on the durability of protection is very 
important. Examination of the degree of fabric shielding with inox yarn as a barrier/shielding against electromagnetic radiation was carried out at frequencies: $0.9 \mathrm{GHz}, 1.8 \mathrm{GHz}, 2.1 \mathrm{GHz}$ and $2.4 \mathrm{GHz}$ before and after the first, third, fifth, seventh and tenth cycle of treatment with solvents perchloroethylene in the dry cleaning and water in the wet cleaning process.

\section{EXPERIMENTAL}

The investigation was carried out on samples of modacryl/cotton blend fabrics with inox yarn whose construction features are listed in Table 1.

Table 1. Construction features of the modacryl/cotton blend fabric with inox fibers

\begin{tabular}{|c|c|}
\hline $\begin{array}{c}\text { Raw material } \\
\text { composition }\end{array}$ & $\begin{array}{c}54 \% \text { modacryl fiber } \\
\text { (MAC); 44\% cotton; } \\
2 \% \text { inox }\end{array}$ \\
\hline $\begin{array}{c}\text { Mass per unit area } \\
\left(\mathrm{g} / \mathrm{m}^{2}\right)\end{array}$ & 258 \\
\hline $\begin{array}{c}\text { Warp thread density } \\
\text { (threads/cm) }\end{array}$ & 36 \\
\hline $\begin{array}{c}\text { Weft thread density } \\
\text { (threads/cm) }\end{array}$ & 38 \\
\hline $\begin{array}{c}\text { Warp yarn fineness } \\
\text { (tex) }\end{array}$ & 39 \\
\hline $\begin{array}{c}\text { Weft yarn fineness } \\
\text { (tex) }\end{array}$ & 0.48 \\
\hline Fabric thickness $(\mathrm{mm})$ & Satin $1 / 4(2)$ \\
\hline Fabric weave & \\
\hline
\end{tabular}

The dark blue shielding satin fabric, in which the inox yarn is inserted in weft direction with repeat $1 \mathrm{~cm}$, was woven at Čateks Company, Čakovec, Figure 2.
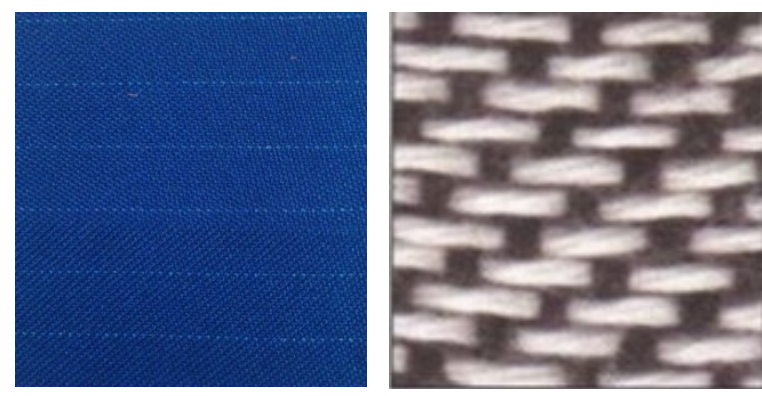

Figure 2. Shielding satin fabric with inox yarn in weft direction

\section{Fabric care}

The electroconductive fabric was tested in the dry cleaning process (DC) through 10 cycles. This process implies perchloroethylene (PERC) treatment with an addition of cleaning booster whose purpose is to colloidally dissolve small quantities of water in PERC having low surface tension and dipole moment. PERC molecules do not aggregate, have greater molecular mobility than water, so they penetrate into the textile material faster and take away dissolved dirt, which speeds up the process. Fastness test of the fabric to PERC in the dry cleaning process was done according to standard HRN EN ISO 13752:2010 [16].

Wet cleaning (WC) is a professional cleaning process in water, with the help of special machines, programs and ecological detergents, which allows the cleaning of extremely sensitive clothing intended for hand-washing and dry cleaning. The role of the special detergent is to remove fine dirt and grease from the textile material and then to keep them in the bath in order not to return to the textile which could diminish the cleaning effect [17, 18]. Fastness test of the material to wet cleaning was done according to HRN EN ISO 3175-4 2010 [19].

\section{Measurement of the effectiveness of electromagnetic shielding}

The effect of the care process on the shielding properties of the fabric was investigated using the method developed at the University of Zagreb, Faculty of Electrical Engineering and Computer Sciences, at the Microwave laboratory, Department of Radiocommunications, under working conditions:

- temperature $23 \pm 1{ }^{\circ} \mathrm{C}$,

- relative humidity $50 \pm 10 \%$.

EM shielding factor was determined as the ratio between the EM field intensity $\left(E_{0}\right)$ measured without the tested fabric and the EM field intensity $\left(E_{1}\right)$ with the fabric placed 
between the radiation source and the measuring device.

Shielding effect, SE (dB) is calculated according to expression (1):

$$
S E=20 \log \frac{E_{0}}{E_{1}}
$$

where:

$E_{\mathrm{o}}-$ field level without shielding,

$E_{1}$ - field level with shielding.

According to the recommendations of international standards IEE-STD 299-97 [20], MIL STD 285 [21] and ASTM D-4935-89 [22], a measuring system was designed which consists of the measuring instrument NARDA SRM 3000, signal generator, horn antenna and $1 \mathrm{~m} \times 1 \mathrm{~m}$ wooden frame shielding into which samples are placed, Figure 3.

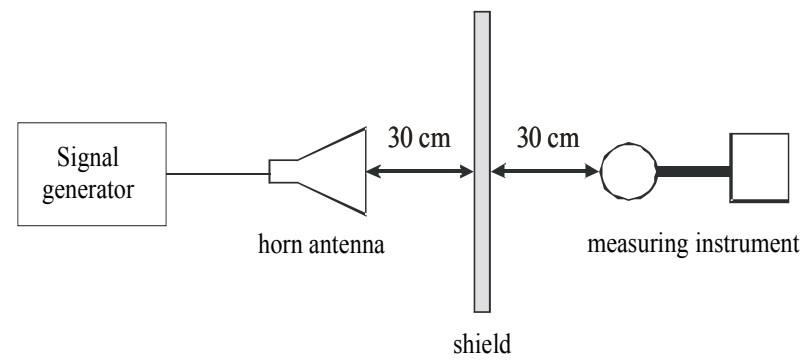

Figure 3. Measuring system

Spectrum analyzers are instruments that measure the strength of the measured field from a particular frequency using frequency sweep over a wider frequency bandwidth and have the ability to process and store results. NARDA SRM 3000 measuring instrument is a portable spectrum analyser that measures the field isotropically, i.e. from any direction and any polarization, making measurements more convenient and simpler. It is intended for EM field measurements in the frequency range between $80 \mathrm{MHz}$ and $3000 \mathrm{MHz}$, where it provides an extremely linear response [23].

The signal generator is an instrument that serves as a source of electromagnetic radiation. Sometimes it has to be used together with a microwave amplifier to obtain higher values of the electromagnetic field. For the purposes of this work a generator of continuous sinusoidal signal at frequencies of $0.9 \mathrm{GHz}, 1.8 \mathrm{GHz}, 2.1 \mathrm{GHz}$ and $2.4 \mathrm{GHz}$ was used.

Horn antenna was named after its shape and is used for receptions and transmissions of microwave signals. During reception it serves to collect and direct radio waves to the waveguide, while during transmission it serves to direct radio waves from the waveguide to the space.

The wooden frame was designed for the purpose of testing the effectiveness of shielding against electromagnetic radiation.

During measurement the wooden frame with a sample is inserted into the wooden stand and fixed to remain in vertical position.

\section{RESULTS AND DISCUSSION}

The results of the effectiveness of the electroconductive fabric before and after 10 cycles of the care process in weft and warp direction as shielding against electromagnetic radiation were obtained after measuring at frequencies of $0.9 \mathrm{GHz}, 1.8 \mathrm{GHz}, 2.1 \mathrm{GHz}$ and $2.4 \mathrm{GHz}$, Tables 2 and 3.

Table 2. SE of the fabric with inox yarn in weft direction before and after 1, 3, 5, 7 and 10 cycles of perchloroethylene treatment (DC)

\begin{tabular}{|c|c|c|c|c|}
\hline $\begin{array}{c}\text { Frequency } \\
(\mathrm{GHz})\end{array}$ & 0.9 & 1.8 & 2.1 & 2.4 \\
\hline Fabric & \multicolumn{4}{|c|}{$\mathrm{SE}(\mathrm{dB})$ of fabric in weft direction } \\
\hline Untreated & 12.6 & 17.73 & 17.98 & 18.53 \\
\hline $\begin{array}{c}\text { DC 1 } \\
\text { cycle }\end{array}$ & 10.33 & 14.21 & 16.73 & 16.19 \\
\hline $\begin{array}{c}\text { DC 3 } \\
\text { cycles }\end{array}$ & 10.2 & 14.01 & 16.4 & 13.58 \\
\hline $\begin{array}{c}\text { DC 5 } \\
\text { cycles }\end{array}$ & 9.84 & 13.22 & 15.14 & 12.08 \\
\hline $\begin{array}{c}\text { DC 7 } \\
\text { cycles }\end{array}$ & 7.3 & 9.65 & 13.87 & 11.54 \\
\hline $\begin{array}{c}\text { DC 10 } \\
\text { cycles }\end{array}$ & 5.01 & 8.46 & 10.39 & 10.01 \\
\hline
\end{tabular}


Table 3. SE of the functional fabric in warp direction after 1, 3, 5, 7 and 10 cycles of perchloroethylene treatment (DC)

\begin{tabular}{|c|c|c|c|c|}
\hline $\begin{array}{c}\text { Frequency } \\
\text { (GHz) }\end{array}$ & 0.9 & 1.8 & 2.1 & 2.4 \\
\hline Fabric & \multicolumn{4}{|c|}{$\mathrm{SE}(\mathrm{dB})$ of fabric in warp } \\
direction \\
\hline Untreated & 5.21 & 2.34 & 6.67 & 9.82 \\
\hline $\begin{array}{c}\text { DC 1 } \\
\text { cycle }\end{array}$ & 4.12 & 1.66 & 4.02 & 7.84 \\
\hline $\begin{array}{c}\text { DC 3 } \\
\text { cycles }\end{array}$ & 3.41 & 1.22 & 1.87 & 2.73 \\
\hline $\begin{array}{c}\text { DC 5 } \\
\text { cycles }\end{array}$ & 2.4 & 0.86 & 1.77 & 1.45 \\
\hline $\begin{array}{c}\text { DC 7 } \\
\text { cycles }\end{array}$ & 0.84 & 0.32 & 1.62 & 1.08 \\
\hline $\begin{array}{c}\text { DC 10 } \\
\text { cycles }\end{array}$ & 0.41 & 0 & 1.23 & 0.41 \\
\hline
\end{tabular}

Table 2 shows that the untreated fabric samples in weft direction at a frequency of 2.4 $\mathrm{GHz}$ have the highest effectiveness of shielding against EM radiation which amounts to $18.53 \mathrm{~dB}$. The effectiveness of shielding against EM radiation measured at all frequencies was reduced with increasing the number of dry cleaning cycles. After 10 cycles were completed, the highest values of the effectiveness of shielding against EM radiation were achieved at frequencies of $2.1 \mathrm{GHz}$ and $2.4 \mathrm{GHz}$ amounting to $10.39 \mathrm{~dB}$.

Figure 4 shows the values of the effectiveness of shielding against EM radiation (SE) of the untreated samples with inox fibers in weft direction before and after 1, 3, 5, 7 and 10 dry cleaning cycles.

It can be seen that the functional fabric with inox yarn has a high degree of shielding at 1.8 $\mathrm{GHz}, 2.1 \mathrm{GHz}$ and $2.4 \mathrm{GHz}$. After the $1^{\text {st }}$ dry cleaning cycle SE (shielding effect) measured at a frequency of $1.8 \mathrm{GHz}$ decreased significantly, while the $3^{\text {rd }}$ cycle caused a great fall of SE at a frequency of $2.4 \mathrm{GHz}$. SE properties of fabric shielding after 10 cycles decrease in comparison with the initial value depending on frequency. The loss of SE properties at $0.9 \mathrm{GHz}$ is about $55 \%$, at 1.8 $\mathrm{GHz}$ about $70 \%$, at $2.1 \mathrm{GHz}$ and at $2.4 \mathrm{GHz}$ about $60 \%$.

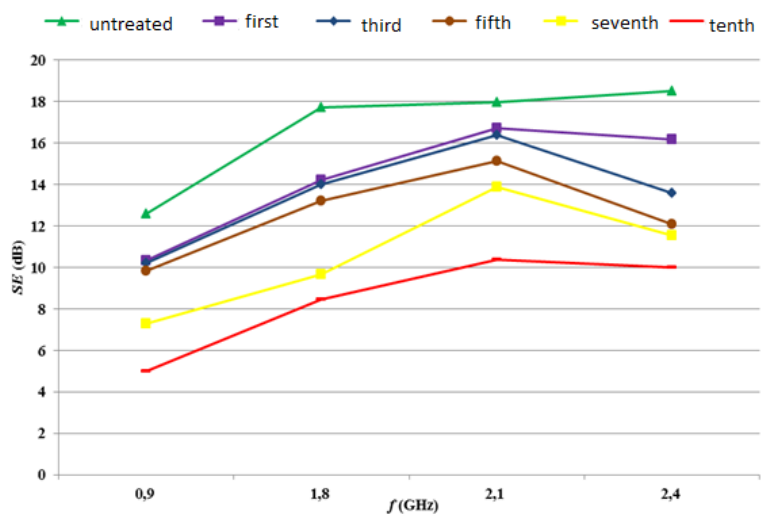

Figure 4. SE of the fabric with inox yarn in weft direction before and after 1, 3, 5, 7 and 10 dry cleaning cycles measured at frequencies of

$0.9 \mathrm{GHz}, 1.8 \mathrm{GHz}, 2.1 \mathrm{GHz}$ and $2.4 \mathrm{GHz}$

The values of the effectiveness of SE functional fabrics as shielding against electromagnetic radiation in warp direction before and after 1, 3, 5, 7 and 10 dry cleaning processes are listed in Table 3.

Inox threads are electroconductive functional elements of the tested fabric inserted into the fabric only in weft direction. Therefore, SE values of the untreated samples are very low in comparison with the samples in weft direction at all tested frequencies. With increasing number of dry cleaning cycles low SE values are additionally reduced, indicating poor electromagnetic shielding properties of fabrics in warp direction.

Figure 5 shows the comparison of all measured values of the effectiveness of the functional fabric in warp direction as shielding against electromagnetic radiation before and after 1, 3, 5, 7 and 10 dry cleaning processes by comparison with the untreated samples on which the lowest values of the SE (untreated and dry cleaned samples) at a frequency of 1.8 $\mathrm{GHz}$ were also observed.

SE values of fabric as shielding against electromagnetic radiation in weft direction before and after 1, 3, 5, 7 and 10 wet cleaning cycles are listed in Table 4. 


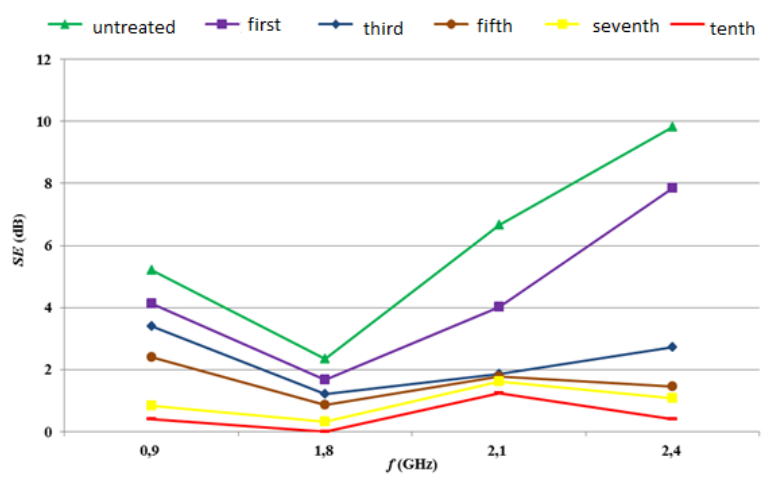

Figure 5. SE of the functional fabric in warp direction before and after 1, 3, 5, 7 and 10 dry cleaning processes measured at frequencies of

$0.9 \mathrm{GHz}, 1.8 \mathrm{GHz}, 2.1 \mathrm{GHz}$ and $2.4 \mathrm{GHz}$

Table 4. SE of samples with inox yarn in weft direction before and after 1, 3, 5, 7 and 10 wet cleaning cycles (WC)

\begin{tabular}{|c|c|c|c|c|}
\hline $\begin{array}{c}\text { Frequency } \\
(\mathrm{GHz})\end{array}$ & 0.9 & 1.8 & 2.1 & 2.4 \\
\hline Fabric & \multicolumn{2}{|c|}{ SE (dB) of fabric in weft direction } \\
\hline Untreated & 12.6 & 17.73 & 17.98 & 18.53 \\
\hline $\begin{array}{c}\text { WC 1 } \\
\text { cycle }\end{array}$ & 11.74 & 16.03 & 16.05 & 14.25 \\
\hline $\begin{array}{c}\text { WC 3 } \\
\text { cycles }\end{array}$ & 8.00 & 14.02 & 14.23 & 13.24 \\
\hline $\begin{array}{c}\text { WC 5 } \\
\text { cycles }\end{array}$ & 7.29 & 12.64 & 12.85 & 11.46 \\
\hline $\begin{array}{c}\text { WC 7 } \\
\text { cycles }\end{array}$ & 6.96 & 12.31 & 12.08 & 10.98 \\
\hline $\begin{array}{c}\text { WC 10 } \\
\text { cycles }\end{array}$ & 6.51 & 11.91 & 11.44 & 10.32 \\
\hline
\end{tabular}

The SE of the samples listed in Table 4 indicate the continuous reduction of shielding properties of the functional fabric after wet cleaning cycles. The reduction of SE values of the fabric after 10 wet cleaning cycles measured at all frequencies is somewhat lower in comparison with SE values after 10 dry cleaning cycles.

Figure 6 shows the comparison of the untreated fabric samples with inox yarn in weft direction before and after wet cleaning measured at all tested frequencies whereby it can be observed that the lowest SE values are at a frequency of $0.9 \mathrm{GHz}$.

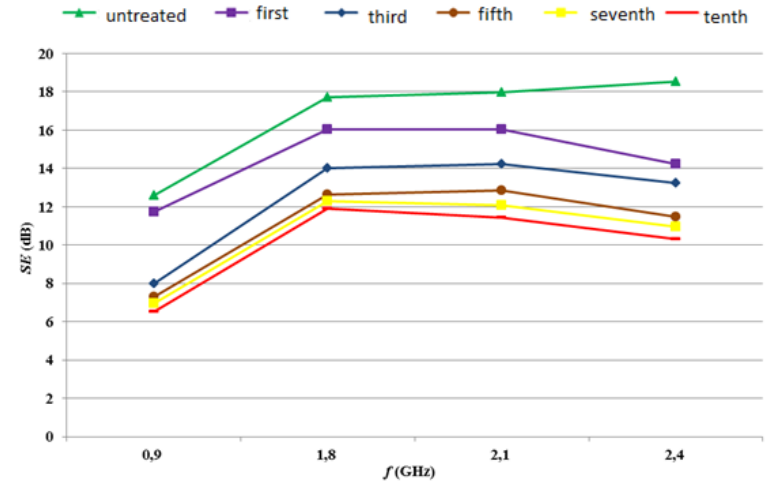

Figure 6. SE of the functional fabric with inox yarn in weft direction before and after 1, 3, 5,

7 and 10 wet cleaning cycles measured at frequencies of $0.9 \mathrm{GHz}, 1.8 \mathrm{GHz}, 2.1 \mathrm{GHz}$ and $2.4 \mathrm{GHz}$

Figure 6 clearly shows the reduction in the SE value of the fabric with inox yarn in weft direction before and after wet cleaning cycles measured at all frequencies. In the figure a higher reduction of SE of fabrics treated in water and measured at a frequency of $2.4 \mathrm{GHz}$ in comparison with frequencies of $1.8 \mathrm{GHz}$ and $2.1 \mathrm{GHz}$ is observed.

The SE values of the fabric in warp direction before and after 1, 3, 5, 7 and 10 wet cleaning cycles as shielding against electromagnetic radiation are listed in Table 5.

Table 5. SE of the functional fabric in warp direction before and after 1, 3, 5, 7 and 10 wet cleaning cycles (WC)

\begin{tabular}{|c|c|c|c|c|}
\hline $\begin{array}{c}\text { Frequency } \\
\text { (GHz) }\end{array}$ & 0.9 & 1.8 & 2.1 & 2.4 \\
\hline Fabric & \multicolumn{2}{|c|}{ SE (dB) of fabric in warp direction } \\
\hline Untreated & 5.21 & 2.34 & 6.67 & 9.82 \\
\hline $\begin{array}{c}\text { WC 1 } \\
\text { cycle }\end{array}$ & 3.74 & 1.23 & 4.1 & 6.87 \\
\hline $\begin{array}{c}\text { WC 3 } \\
\text { cycles }\end{array}$ & 2.8 & 0.84 & 2.81 & 2.6 \\
\hline $\begin{array}{c}\text { WC 5 } \\
\text { cycles }\end{array}$ & 1.75 & 0.5 & 1.66 & 1,35 \\
\hline $\begin{array}{c}\text { WC 7 } \\
\text { cycles }\end{array}$ & 1.55 & 0.46 & 0.46 & 1.08 \\
\hline $\begin{array}{c}\text { WC 10 } \\
\text { cycles }\end{array}$ & 0.73 & 0.26 & 0 & 0.71 \\
\hline
\end{tabular}


The SE values of the functional fabric in warp direction after the performed wet cleaning cycles are as low as the values of these fabrics after dry cleaning. After 5 wet cleaning cycles shielding values against electromagnetic radiation at all tested frequencies are below 2 $\mathrm{dB}$ indicating poor shielding properties.

Figure 7 shows the comparison of the SE values of functional fabrics in warp direction before and after 1, 3, 5, 7 and 10 wet cleaning cycles. It can be seen that the untreated fabrics and the fabric after the first wet cleaning cycle have the highest $\mathrm{SE}$ values measured at a frequency of $2.4 \mathrm{GHz}$. The $\mathrm{SE}$ values of fabrics after the third wet cleaning cycle considerably decrease, and further cycles cause a significant reduction of the SE values in comparison with the untreated functional fabric.

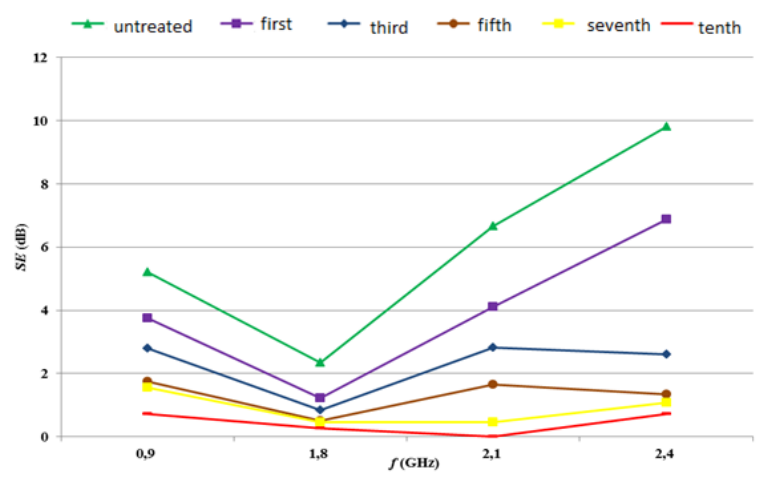

Figure 7. SE of the functional fabric in warp direction before and after 1, 3, 5, 7 and 10 wet cleaning cycles measured at frequencies of 0.9 $\mathrm{GHz}, 1.8 \mathrm{GHz}, 2.1 \mathrm{GHz}$ and $2.4 \mathrm{GHz}$

\section{CONCLUSION}

The paper presents the investigation of functional conductive fabric which consists of two textile components: modacryl/cotton and non-textile component: inox yarn which is every $1 \mathrm{~cm}$ inserted only in weft direction (transverse threads in the fabric). Measurements of the SE values of the textile shielding before and after 10 treatment cycles in dry and wet cleaning were taken in warp and weft direction. Shielding effect (SE) testing of the electroconductive fabric before and after treatment in solvents, perchloroethylene and water, as shielding against electromagnetic radiation was carried out at frequencies of $0.9 \mathrm{GHz}, 1.8 \mathrm{GHz}, 2.1$ $\mathrm{GHz}$ and $2.4 \mathrm{GHz}$. Shielding properties of the fabric in weft direction are satisfactory at frequencies of $1.8 \mathrm{GHz}, 2.1 \mathrm{GHz}$ and $2.4 \mathrm{GHz}$, while they are extremely poor in warp direction.

The SE values of the functional electroconductive fabric in weft direction after 10 dry and wet cleaning cycles at frequencies of $0.9 \mathrm{GHz}, 2.1 \mathrm{GHz}$ and $2.4 \mathrm{GHz}$ confirmed that the wet cleaning process is more acceptable for the care of this shielding fabric than the dry cleaning process. An additional contribution of the wet cleaning process is manifested in a better environmental profile compared with dry cleaning.

\section{REFERENCES}

[1] K. Malarić, Zaštita radiokomunikacijskih sustava, Sveučilište u Zagrebu, Fakultet elektrotehnike i računarstva, Zagreb, 2005.

[2] M. Ammari, A. Lecomte, M. Sakly, H. Abdelmelek, R. de-Seze, Exposure to GSM $900 \mathrm{MHz}$ Electromagnetic Fields Affects Cerebral Cytochrome Coxidase Activity, Toxicology 250(2008) 1, 7074.

[3] C. Sage, D.O. Carpenter, A Rationale for Biologically-based Exposure Standards for Low-Intensity Electromagnetic Radiation, BioInitiative, USA, December 31 ${ }^{\text {st }}, 2012$.

[4] V.I.T. Ahamed, N.G. Karthick, P.K. Joseph, Effect of Mobile Phone Radiation on Heart Rate Variability, Computers in Biology and Medicine 38(2008) 6, 709-712.

[5] X. Shangcheng, Z. Zhou, Z. Lei, Y. Zhengping, Z. Wei, W. Yuan, W. Xubu, L. Maoquan, C. Yang, C. Chunhai, H. Mindi, Z. Guangbin, Z. Min, Exposure to $1800 \mathrm{MHz}$ Radiofrequency Radiation 
Induces Oxidative Damage to Mitochondrial DNA in Primary Cultured Neurons, Brain Research 1311(2010), 189-196.

[6] B.S. Saini, A. Pandey, Effect of Mobile Phone and BTS Radiation on Heart Rate Variability, International Journal of Research in Engineering and Technology 2(2013) 4, $662-666$.

[7] S Brzezinski, T. Rybicki, I. Karbownik, G. Malinowska, E. Rybicki, L. Szugajew, M. Lao, K. Sledzinska, Textile Multi-layer Systems for Protection against Electromagnetic Radiation, Fibres \& Textiles in Eastern Europe 17(2009) 2/73, 66-71.

[8] E. Hakansson, A. Amiet, A. Kaynak, Electromagnetic Shielding Properties of Polypyrrole/Polyester Composites in the 1-18 GHz frequency range, Synthetic metals 156(2006) 14-15, 917-925.

[9] K.B. Cheng, S. Ramakrishna, K.C. Lee, Development of Conductive Knitted Fabric Reinforced Thermoplastic Composites for Electromagnetic Shielding Applications, Journal of Thermoplastic Composite Materials (2000) 13, 378-399.

[10] K.B. Cheng, T.W. Cheng, R.N. Nadaraj, Electromagnetic Shielding Effectiveness of the Twill Copper Woven Fabrics, Journal of Reinforced Plastics and Composites 25(2006) 7, 699-709.

[11] J.S. Roh, Y.S. Chi, T.J. Kang, S.W. Nam, Electromagnetic shielding effectiveness of multifunctional metal composite Fabrics, Textile Research Journal 78(2008) 9, 825-835.

[12] V. Safarova, J. Militky, Multifunctional Metal Composite Textile Shields Against Electromagnetic Radiation Effect of Various Parameters on Electromagnetic Shielding Effectiveness, Polymer Composite 38(2015), 309-323.

[13] A. Das, V.K. Kothari, A. Kothari, A. Kumar, Effect of Various Parameters on Electromagnetic Shielding Effectiveness of Textile Fabrics, Indian Journal of Fibers \& Textile Research 34(2009) 6, 144-148.
[14] M. Sonehara, T. Sato, M. Takasaki, H. Koniski, K. Yamasawa, Y. Mura, Preparation and Characterization of Nanofiber Nonwoven Textile for Electromagnetic Wave Shielding, IEEE Transactions on Magnetics 44(2008) 11, 3107-3110.

[15] K.B. Cheng, S. Ramakrishna, K.C. Lee, Electromagnetic Shielding Effectiveness of Copper Glass Fiber Knitted Fabric Reinforced Polypropylene Composites, Composites Part A(2000) 31, 1039-1045

[16] HRN EN ISO 3175-2:2010 Tekstil Profesionalna njega, kemijsko čišćenje i mokro čišćenje tkanina i odjevnih predmeta - 2. dio: Postupak ispitivanja učinka čišćenja i završne obrade tetrakloretilenom (ISO 3175-2:2010; EN ISO 3175-2:2010) - Textiles Professional care, dry cleaning and wet cleaning of fabrics and garments - Part 2: Procedure for testing performance when cleaning and finishing using tetrachloroethene (ISO 3175-2:2010; EN ISO 3175-2:2010).

[17] I. Soljačić, T. Pušić, Čišćenje u vodi mokro čišćenje, Tekstil 53(2004) 8, 392398.

[18] T. Pušić, A. Tarbuk, T. Dekanić, M. Laljek, Wet cleaning - recent developments, Tekstil 57(2008) 1-2, 4048.

[19] HRN EN ISO 3175-4:2010 Tekstil Profesionalna njega, kemijsko čišćenje i mokro čišćenje tkanina i odjevnih predmeta - 2. dio: Postupak ispitivanja učinka čišćenja i završne obrade tetrakloretilenom (ISO 3175-2:2010; EN ISO 3175-2:2010) - Textiles Professional care, dry cleaning and wet cleaning of fabrics and garments - Part 4: Procedure for testing performance when cleaning and finishing using wet cleaning (ISO 3175-4:2010; EN ISO 3175-4:2010).

[20] IEEE STD 299 Standard Method for Measuring the Effectiveness of Electromagnetic Shielding Enclosures, 299, 2006.

[21] MIL-STD-285, Military Standard: Attenuation Measurements for 
Enclosures, Electromagnetic Shielding, 1956.

[22] ASTM D-4935-89 Standard Test Method for Measuring the Electromagnetic Shielding Effectiveness of Planar Materials, 1999.

[23] K. Malarić, D. Šimunić, R. Zenter, Ekonomija i ekologija radiokomunikacijskih sustava, Sveučilište u Zagrebu Fakultet elektrotehnike i računarstva, Zagreb, 2016.

\section{Acknowledgements}

This work has been fully supported by Croatian Science Foundation under the project (IP-201801-7028). 